\title{
IMPLEMENTASI PEMBELAJARAN DI LUAR KELAS BERBASIS KETERAMPILAN BERPIKIR KRITIS SISWA PADA KELAS V TEMA 4 SUBTEMA 1 PEMBELAJARAN 4 SDN KETABANG SURABAYA
}

\author{
Sabrina Zamzamiatul Sofa ${ }^{1}$, Triman Juniarso ${ }^{2}$, Pana Pramulia ${ }^{3}$ \\ Pendidikan Guru Sekolah Dasar, Universitas PGRI Adi Buana Surabaya, Surabaya, Indonesia \\ Sabrinazamzam99@gmail.com, trimanunipa@gmail.com, panapramulia@unipasby.ac.id
}

\begin{abstract}
Informasi Artikel Abstract

\section{Kata Kunci:}

Metode pembelajaran,

Luar kelas,

Kemampuan berpikir kritis,

Tematik

Diterima: 24-09-2020

Disetujui: 07-10-2020

Dipubikasikan: 25-11-2020

Penelitian ini merupakan penelitian kualitatif deskriptif. Untuk memperoleh data dalam pembelajaran keterampilan berpikir kritis di SDN Ketabang Surabaya, peneliti menggunakan sumber data primer dan data sekunder. Penelitian ini menekankan pada berpikir kritis siswa kelas $\mathrm{V}$ melalui penerapan metode pembelajaran di luar kelas. Tujuan penelitian ini adalah 1) Mengetahui pelaksanaan pembelajaran di luar kelas, 2) Mengetahui dampak penerapan metode pembelajaran di luar kelas terhadap keterampilan berpikir kritis siswa kelas V SDN Ketabang Surabaya. Teknik pengumpulan data yang digunakan adalah observasi, wawancara dan dokumentasi. Analisis data menggunakan analisis interaktif yang terdiri dari pengumpulan data, reduksi data, penyajian data, dan penarikan kesimpulan. Hasil penelitian menunjukkan bahwa: 1) Penerapan metode pembelajaran di luar kelas dalam meningkatkan keterampilan berpikir kritis siswa. 2) Dampak penerapan metode pembelajaran di luar kelas terhadap keterampilan berpikir kritis siswa. Kesimpulan dari penelitian ini adalah pelaksanaan pembelajaran di luar kelas dapat meningkatkan keterampilan berpikir kritis siswa kelas $\mathrm{V}$ dapat diterapkan dalam proses pembelajaran dengan materi yang sesuai.
\end{abstract}

\section{PENDAHULUAN}

Salah satu media untuk pengembangan diri adalah pendidikan. Dengan pendidikan seseorang akan dapat menjadi manusia yang berkualitas dan memiliki potensi. Dengan kualitas dan potensi yang mumpuni, manusia akan dapat bersaing di era industri 4.0 ini. Pendidikan juga dapat menjadi alat untuk pengembangan kemampuan berpikir. Berdasarkan hal tersebut, telah banyak cara yang dilakukan sebagai usaha peningkatan kualitas pendidikan nasional. Tujuannya agar produk pendidikan berdaya saing tinggi, sehingga dipercaya masyarakat secara luas. 
Pada era industri 4.0 saat ini, perbaikan kualitas pendidikan di Indonesia dalam segala sektor dibutuhkan, karena persaingan yang semakin ketat dan juga tuntutan zaman (Rachmadtullah et al. 2020). Dinamika perkembangan zaman menuntut dunia pendidikan untuk berkembang, diperbaiki, serta diinovasi. Salah satu pilar penting dalam sebuah negara adalah kualitas pendidikan, maka hal yang penting menyiapkan sumber daya manusia yang siap menghadapi tuntutan zaman dalam berbagai dimensi kehidupan.

Undang-Undang No. 20 tahun 2003 Tentang Sistem Pendidikan Nasional, menyatakan bahwa: Pendidikan adalah usaha sadar dan terencana untuk mewujudkan suasana belajar dan proses pembelajaran agar siswa secara aktif mengembangkan potensi dirinya untuk memiliki kekuatan spiritual/keagaman, pengendalian diri, kepribadian, kecerdasan, akhlak mulia, serta keterampilan yang dimiliki dirinya, masyarakat, bangsa, dan negara (Permendikbud No. 104:2014).

Dalam pembelajaran salah satu tujuan yang ingin dicapai, yaitu mencetak siswa agar mempunyai kemampuan berpikir kritis, sehingga dapat memahami berbagai konsep dan kepekaan dalam memecahkan masalah yang dihadapi dalam kehidupan sehari-hari. Berpikir kritis merupakan hasil dari disiplin, pemantauan, kemauan dan keberanian memperbaiki pikiran sendiri agar dapat berkomunikasi dan memecahkan permasalahan secara efektif. Seringkali dijumpai pembelajaran, khususnya di sekolah dasar proses belajar mengajar yang tidak dapat dikembangkan secara optimal, bahkan tidak sedikit guru yang mengabaikan pentingnya siswa berpikir kritis. Artinya, siswa sekolah dasar belum mampu diajak dan diarahkan untuk berpikir kritis dalam menghadapi permasalahan. Dalam hal ini, guru hanya melakukan kegiatan transfer pengetahuan tanpa melibatkan siswa untuk mengembangkan kemampuan berpikir kritis. Mencermati fakta tersebut dibutuhkan strategi sebagai usaha pengembangan kemampuan berpikir kritis siswa secara optimal.

Dalam proses kegiatan belajar mengajar belajar, siswa menggunakan kemampuan mentalnya untuk mempelajari dan memahami materi. Kemampuan-kemampuan kognitif, afektif, psikomotorik yang dibelajarkan dengan bahan belajar menjadi semakin rinci dan menguat (Dimyati dan Mudjiono 2002:22). Guru harus berusaha menciptakan lingkungan belajar yang dapat menggali dan mengembangkan kemampuan siswa serta melibatkan pembelajaran bermakna yang lebih berpusat pada siswa (student centered), agar kemampuankemampuan siswa dapat terintegrasikan dengan baik. Sistem pembelajaran yang berpusat pada siswa akan menumbuhkan dan mengembangka kreativitas dan melatih kemampuan berpikir kritis siswa dalam pembelajaran maupun memecahkan permasalahan yang dihadapi dalam kehidupan sehari-hari.

Salah satu kelemahan proses pembelajaran yang dilaksanakan para guru, yaitu kurangnya usaha pengembangan kemampuan berpikir siswa (Sanjaya, 2007:224). Artinya, guru menuntut siswa hanya untuk menampung dan menghafal semua materi yang telah diajarkan tanpa mengarahkan siswa kepada tuntutan untuk memahami informasi secara holistik, serta mengaitkannya dengan kehidupan sehari-hari. Persoalan tersebut sering ditemui di berbagai instansi sekolah. Dengan demikian dapat dikatakan, bahwa proses belajar mengajar memiliki banyak kelemahan. Dalam hal ini, guru mempunyai kesan menuntut siswa untuk belajar 
tanpa memberikan bimbingan cara belajar, serta tidak mendidik siswa untuk berpikir kritis, dan menyelesaikan masalahnya dalam kehidupan sehari-hari.

Dalam melaksanakan metode pembelajaran di luar kelas, sebelumnya guru harus mengetahui langkahlangkah pembelajaran di luar kelas. Pembelajaran di luar kelas merupakan cara guru mengajar dengan membimbing siswa di lapangan atau pembelajaran yang menggunakan alam sebagai sumber belajar. Salah satu hal penting yang berperan dalam pertumbuhan dan perkembangan anak adalah lingkungan. Anak kali pertama belajar dan memahami apa saja dari lingkungannya. Husamah (2013:2) menyatakan, bahwa pendekatan lingkungan dibutuhkan dalam proses belajar mengajar dan memahamkan konsep kepada siswa agar dapat mewujudkan tujuan yang diinginkan.

Berkaitan dengan tuntutan kualitas pendidikan nasional yang mengharapkan sumber daya manusia mempunyai kemampuan intelektual tinggi dan berpikir kritis, dibutuhkan adanya perbaikan kualitas pendidikan yang dapat dilakukan, salah satunya melalui perbaikan metode pembelajaran. Tipe pembelajaran dalam proses penyampaian materi pembelajaran ditentukan oleh metode pembelajaran yang diterapkan. Penerapan metode pembelajaran tersebut dapat digunakan untuk menentukan keberhasilan proses pembelajaran yang dilaksanakan. Keberhasilan tipe pembelajaran akan berpengaruh terhadap kualitas pendidikan. Dalam proses pembelajaran di sekolah dasar guna mengembangkan kemampuan berpikir kritis siswa, metode yang inovatif dan tepat merupakan salah satu kebutuhan yang harus diperhatikan.

Metode pembelajaran di luar kelas mempunyai daya guna mengaktifkan siswa. Artinya, metode ini membuat siswa dapat tetap belajar sambil bermain di luar kelas tanpa adanya rasa bosan. Pembelajaran di luar kelas merupakan salah satu metode pembelajaran yang memanfaatkan alam sebagai sumber belajar. Anakanak dapat belajar secara lebih mendalam melalui objek-objek yang dihadapi dari pada jika hanya belajar belajar di dalam kelas yang memiliki banyak keterbatasan.

Berdasarkan latar belakang di atas maka, peneliti melakukan penelitian skripsi dengan judul "Implementasi Metode Pembelajaran di Luar Kelas berbasis Keterampilan Berpikir Kritis Pada Kelas V Tema 4 Sehat Itu Penting Subtema 1 Peredaran Darahku Sehat Pembelajaran 4 SDN Ketabang Surabaya”.

\section{METODE PENELITIAN}

Ada dua metode yang sangat populer dalam penelitian, yaitu metode kuantitatif dan metode kualitatif. Menurut Sugiyono (2014: 9) metode penelitian tersebut berlandaskan pada filsafat postpositivisme yang digunakan terhadap kondisi objek yang alamiah. Dalam hal ini peneliti sebagai instrumen kunci. Teknik pengumpulan data dilakukan secara triangulasi (gabungan), sedangkan analisis data bersifat induktif/kualitatif, dan memberi penekanan terhadap makna dari generalisasi, yaitu hasil penelitian kualitatif.

Pada penelitian ini, pendekatan yang digunakan adalah pendekatan kualitatif deskriptif. Peneliti, akan terjun langsung ke lapangan untuk mengambil data yang diperlukan dalam penelitian. Sehingga hasil penelitian 
yang didapatkan akan lebih objektif. Jenis penelitian pada penelitian ini adalah deskriptif kualitatif, artinya penelitian ini dimaksudkan untuk meningkatkan keterampilan berpikir kritis siswa kelas V tema 4 subtema 1 pembelajaran 4 SDN Ketabang Surabaya.

Data dalam penelitian ini adalah data hasil observasi, data hasil wawancara, dan data hasil dokumentasi. Pengumpulan data dilakukan dengan menggunakan teknik observasi, wawancara, dan dokumentasi. Teknik analisis data yang digunakan adalah menggunakan model Miles and Huberman yaitu dilakukan dengan pengumpulan data, reduksi data, penyajian data, dan penarikan kesimpulan. Teknik keabsahan data yang digunakan dalam penelitian ini adalah uji kredibilitas menggunakan triangulasi sumber dan teknik. Triangulasi sumber digunakan untuk menguji data hasil wawancara dari dua narasumber, sedangkan triangulasi teknik digunakan untuk menguji data hasil wawancara, observasi, dan dokumentasi.

\section{HASIL DAN PEMBAHASAN}

\section{Hasil Penelitian}

Penelitian ini dilakukan pada tanggal 16 September sampai dengan 16 November 2019 di SDN Ketabang, Jln. Seruni No. 6 Kelurahan Ketabang, Kecamatan Genteng Kota Surabaya. Penelitian ini bersifat kualitatif yang akan menguraikan hasil secara deskriptif. Hasil penelitian dianalisis berdasarkan rumusan masalah yang sudah disebutkan di Bab I. Dalam analisis peneliti akan menggambarkan dan menguraikan seluruh data yang terkumpul sehingga mampu memperoleh gambara secara umum dan menyeluruh. Sebelum menjawab rumusan masalah, peneliti akan memaparkan deksripsi lokasi dan visi misi sekolah sebagai berikut.

\section{- Deskripsi Lokasi dan Visi dan Misi Sekolah}

Sekolah Dasar Negeri Ketabang adalah salah satu sekolah yang terletak di pusat kota, tepatnya berlokasi di Jln. Seruni No. 6 Kelurahan Ketabang, Kecamatan Genteng Kota Surabaya. Berdasarkan bukti buku induk yang ada, SDN Ketabang Surabaya berdiri sejak tahun 1947. Namun dalam perkembangannya SDN Ketabang Surabaya yang sekarang adalah hasil marger dari dua sekolah yaitu SDN Ketabang III Surabaya dan SDN Ketabang IV Surabaya, sesuai dengan SK Walikota No. 188.45/201/436.1.2/2007. Lokasi SDN Ketabang Surabaya letaknya sangat strategis, berada di tengah pemukiman penduduk dan dekat dengan pusat pemerintahan kota serta mudah dijangkau oleh kendaraan umum maupun pribadi. Sehingga SDN Ketabang merupakan salah satu sekolah yang menjadi salah satu pilihan masyarakat untuk menyekolahkan anaknya di SDN Ketabang Surabaya.

\section{- Visi dan Misi SDN Ketabang Surabaya}

VISI

"Terciptanya sekolah anak ramah, unggul dalam prestasi, berkarakter, dan berwawasan lingkungan IMTAQ dan IPTEK" 
MISI

a. Meningkatkan iman dan taqwa kepada Tuhan Yang Maha Esa melalui intrakulikuler maupun kegiatan-kegiatan peningkatan keimanan dan ketaqwaan.

b. Mengunggul kembangkan semangat kompetensi secara sehat dalam prestasi akdemik maupun non akademik.

c. Menumbuh kembangkan sikap toleransi berwawaskan pergaulan global agar tercipta rasa sikap estetika, etika berdasarkan pancasila.

d. Mendorong dan membantu siswa agar mengenal potensi diri sendiri.

e. Menciptakan lingkungan sekolah yang aman, rapi, bersih, dan nyaman.

f. Mengembangkan budaya gemar membaca rasa ingin tahu, bertolenransi, bekerja sama, saling menghargai, disiplin juur, kerja keras, kreatif, dan mandiri.

g. Membudadayakan budaya 3S yaitu senyum, salam, sapa pada seluruh warga sekolah.

h. Budayakan kedisiplinan dalam pelayanan pendidikan.

i. Membudayakan sikap hati bersih, sehat, dan peduli lingkungan.

j. Menyiapkan generasi unggul yang memiliki potensi di bidan IMTAQ dan IPTEK.

\section{- Deskripsi Hasil Penelitian}

Penelitian ini dilakukan oleh peneliti pada tanggal 16 September sampai dengan 16 November 2019 di SDN Ketabang, Jln. Seruni No. 6 Kelurahan Ketabang, Kecamatan Genteng Kota Surabaya. Teknik pengumpulan data yang dilakukan oleh peneliti adalah observasi, wawancara, tes uraian, dan dokumentasi. Peneliti menggunakan dua kali penelitian untuk mengambil data. Hasil yang diperoleh dalam penelitian pertama adalah empat indikator, antara lain:

a. Kemampuan siswa mencari pernyataan yang jelas dari setiap pertanyaan. Pada indikator ini, kemampuan berpikir kritis siswa dapat dilihat melalui observasi, yaitu siswa mampu merumuskan pokok-pokok permasalahan yang dihadapi. Hal ini diamati melalui partisipasi aktif siswa dalam diskusi kelompok.

b. Siswa berusaha mengetahui informasi dengan baik. Pada indikator ini, kemampuan berpikir kritis siswa dapat dilihat melalui observasi. Siswa menggunakan sumber belajar yang lain serta informasi yang dimiliki melalui pengalaman yang bermaknanya melalui kegiatan diskusi bersama kelompoknya.

c. Siswa bersikap dan berpikir terbuka. Pada indikator ini kemampuan berpikir kritis siswa dapat dilihat melalui observasi, yaitu saat melakukan diskusi kelompok dan pada saat turnamen akademik.

d. Siswa mencari penjelasan sebanyak mungkin. Pada indikator ini, kemampuan berpikir kritis siswa dapat dilihat melalui observasi, yaitu siswa mengajukan pertanyaan berkelanjutan hingga memahami secara utuh. 


\section{Hasil yang diperoleh dalam penelitian kedua adalah empat indikator, antara lain:}

a. Kemampuan siswa mencari alasan. Pada indikator ini, kemampuan berpikir kritis siswa dapat dilihat melalui observasi. Yaitu, siswa menjawab pertanyaan ataupun memberikan tanggapan kepada anggota kelompok lain pada saat melakukan kegiatan turnamen akademik.

b. Siswa memperhatikan situasi dan kondisi secara keseluruhan. Pada indikator ini, kemampuan berpikir kritis siswa dapat dilihat dari observasi, yaitu siswa melakukan proses pembelajaran dengan tertib.

c. Siswa mengambil posisi ketika ada bukti cukup untuk melakukan sesuatu. Pada indikator ini, kemampuan berpikir kritis siswa dapat dilihat melalui observasi, yaitu siswa dapat memberikan alternatif jawaban antara dua teman yang mengajukan pendapat dan menanggapi pendapat.

d. Siswa bersikap secara sistematis dan teratur dengan bagian-bagian dari keseluruhan masalah. Pada indikator ini, kemampuan berpikir kritis siswa dapat dilihat melalui observasi, yaitu siswa melakukan aktivitas pembelajaran dari awal sampai akhir dan melaksanakan prosedur pembelajaran dengan baik.

Penelitian yang telah diperoleh, berikut ini hasilnya:

\section{Suasana Proses Pembelajaran}

Dari hasil observasi proses pembelajaran yang peneliti lakukan dari tanggal 16 September 2019 sampai dengan 16 November 2019 disajikan data sebagai berikut, 1) Bahwa kelas V A pada saat pembelajaran berlangsung dari mulai kegiatan pembuka; 2) Kegiatan inti sampai kegiatan penutup siswa mendengarka dengan baik apa yang telah disampaikan oleh guru.

Permasalahan yang sering muncul dalam pembelajaran berlangsung yaitu di antaranya adanya siswa yang terkadang sibuk sendiri, berbicara dengan teman yang di sebelahnya, menggambar di buku atau coret-coret buku dan konsentrasi siswa terganggu karena ada anak yang sedang berolahraga di lapangan serta yang sering masih terjadi kesalahan terkadang guru masih sulit untuk menyangkut-pautkan materi ajar yang ada karena terkadang pemisahan materi ajar masih terlihat pada saat proses pembelajaran. Masih terdapat siswa yang belum bisa fokus saat guru menjelaskan materi ajar sehingga masih ada siswa yang belum bisa berpikir kritis untuk menjawab pertanyaan-pertanyaan yang diberikan oleh guru.

Implementasi metode pembelajaran ini melalui kegiatan pembelajaran tidak terlepas pula dari suatu kendala. Kendala bisa saja terjadi karena beberapa faktor. Kendala tersebut tentu bukanlah suatu hal yang diinginkan oleh setiap orang. Namun, tak bisa dipungkiri bahwa setiap kegiatan dalam pelaksanaannya tentu sedikit atau banyak akan menemukan suatu kendala.

Dalam implementasi metode pembelajaran di luar kelas melalui kegiatan pembelajaran di SDN Ketabang Surabaya terdapat beberapa kendala. Yang pertama kendala tersebut berasal dari siswa. Tidak semua siswa mampu konsentrasi saat guru memberikan materi, tidak semua siswa mampu berperan aktif dalam diskusi 
kelompok dan tida semua siswa mampu berpikir kritis saat pembelajaran berlangsung. Tentu ada satu atau dua siswa yang kurang mendukung dan menghambat jalannya kegiatan pembelajaran. Misalnya, siswa yang tidak serius dan melihat pekerjaan kelompok sebelahnya saat mengerjakan tugas, kemudian terdapat anggota kelompok yang tidak mau membantu dalam mengerjakan tugas saat berdiskusi kelompok, kemudian saat presentasi di depan kelompok lainnya bersama anggota kelompok masih ada beberapa anggota kelompok yang terlihat tidak siap dan kurangnya kekompakan, dan masih banyak siswa yang kurang mampu dalam menyimpulkan kegiatan pembelajaran yang telah dilakukan pada hari itu. Selain itu, kendala lain muncul dari lingkungan. Hal tersebut disebabkan lingkungan di sekolah sangat padat dengan kegiatannya masing-masing, seperti ada siswa kelas lainnya sedang berolahraga, kemudian ada siswa yang mondar-mandir lewat dan banyak kegiatan lainnya.

Sebenarnya, kendala yang dialami dalam implementasi metode ini melalui kegiatan pembelajaran di SDN Ketabang Surabayai ini tidak terlalu berat, karena sebagaian banyak siswa kelas V A mudah untuk diatur sehingga masih bisa dikendalikan oleh guru.

\section{a. Solusi Yang Dilakukan Guru}

Perlakuan yang dilakukan oleh guru sering memberikan ice breaking kepada siswa yang merasa bosan melalui permainan sederhana yang bisa membuat anak berpikir kritis, seperti permainan "Siapakah aku?". Dari permainan itu siswa dapat berpikir jawaban dan permainannya berkaitan dengan materi yang telah diajarkan. Guru harus mampu menguasai materi yang diajarkan, sehingga pembelajaran tidak terkesan hanyan bermain saja, tetapi siswa juga mampu memahami apa saja materi yang telah diajarkan.

Pada metode pembelajaran di luar kelas, guru mampu mengondisikan siswa sehingga kondisi kelas tetap efektif dan efisien, sehingga materi ajar yang disampaikan guru menstimulus siswa turut aktif dalam proses pembelajaran. Pada saat guru memberikan pertanyaan-pertanyaan, siswa berperan aktif dalam proses pembelajaran dan mendorong meningkatnya kemampuan berpikir kritis siswa. Guru juga berperilaku baik kepada siswa sehingga siswa tidak takut lagi dengan guru.

Guru ketika pembelajaran berlangsung mampu melaksanakan 4C secara baik, yaitu Communication (komunikasi) dengan melalui kegiatan mentransfer sebuah informasi baik secara lisan maupun tulisan, Collaboration (kolaborasi) yang dimana guru dan siswa mampu bekerja sama dengan baik, saling bersinergi, beradaptasi dalam berbagai peran dan tanggungjawab, Critical Thinking and Problem Solving (berpikir kritis dan pemecahan masalah) yang dimaknai dengan kemampuan menalar, memahami, dan membuat pilihan yang rumit, memahami dan menyelasaikan masalah, Creativity and Innovation (Kreativitas dan Inovasi) adalah kemampuan untuk mengembangkan, melaksanakan, dan menyampaikan gagasan-gagasan baru kepada yang lain.

Berikut adalah tahap-tahap selama pembelajaran yang terdiri dari kegiatan pembuka pembelajaran, kegiatan inti pembelajaran, dan kegiatan penutup pembelajaran. 
- Kegiatan Pembuka Pembelajaran

Hasil observasi di kelas V A pada tanggal 10 Oktober 2019 pukul 06.45 sampai dengan 07.00, siswa di depan kelas untuk melakukan baris berbaris yang bertujuan agar siswa disiplin mulai dari awal pembukaan belajar sampai dengan kegiatan penutup. Pada saat itu peneliti mengobservasi siswa yang sedang berbaris dan secara bergantian siswa masuk kelas dengan tertib. Setelah semua siswa duduk di bangkunya masing-masing, kemudian ketua kelas mempimpin berdoa dan menyanyikan lagu Indonesia Raya dan yel-yel PPK. Setelah semua kegiatan pembuka dilakukan, guru memberikan apersepsi dan menjelaskan peraturan pembelajaran yang dilaksanakan di luar kelas sehingga siswa tahu dan pembelajarn yang dilakukan akan berjalan sesuai dengan yang diharapkan. Kemudian guru membagi siswa menjadi 9 kelompok dan mengarahkan siswa untuk keluar kelas dengan kelompoknya masing-masing dan tetap dalam keadaan tertib.

- Kegiatan Inti Pembelajaran

Pada penelitian kegiatan pembelajaran Kelas V Tema 4 Subtema 1 Pembelajaran 4, siswa membuka buku siswa Tema Subtema 1 Pembelajaran 4 kemudian siswa mengamati kegiatan gambar Siti dan teman-temannya. Setelah itu, siswa melakukan identifikasi gambar kegiatan Siti sebagai tanggung jawab dalam kelompok.

Setelah mengamati gambar Siti, kemudian siswa melakukan identifikasi gambar kegiatan Siti sebagai bentuk tanggung jawab dalam kelompok. Identifikasi hasil diskusi siswa ditulis pada selembar kertas yang telah diberikan oleh guru pada setiap kelompok, kemudian guru bersama siswa membahas hasil identifikasi tentang bentuk tanggung jawab dalam kelompok. Setiap kelompok maju untuk membacakan hasil diskusinya.

- Kegiatan Penutup Pembelajaran

Menyimpulkan kegiatan pembelajaran pada hari itu. Dari rangkaian kegiatan pembelajaran yang termuat dalam RPP, mulai dari kegiatan pembuaka pembelajaran, kegiatan inti pembelajaran, terdapat kegiatan penutup pembelajaran. Pada kegiatan penutup pembelajaran siswa diajak oleh guru untuk melakukan refleksi dan menyimpulkan kegiatan pembelajaran yang telah dilakukan. Guru selalu bertanya kepada siswa pembelajaran apa yang telah mereka lakukan kemudian secara mandiri siswa menyimpulkan kegiatan-kegiatan yang telah mereka lakukan pada hari itu. Jadi bukan guru yang menyimpulkan pembelajaran akan tetapi siswa yang menyimpulkan sendiri pembelajaran yang telah dilakukan.

Akan tetapi tidak semua siswa mampu menyimpulkan sendiri kegiatan pembelajaran yang telah dilakukan. hanya terdapat 3 sampai 4 siswa saja dari 35 siswa yang mampu menyampaikan kesimpulan pembelajaran. Sedangkan siswa yang lain hanya meniru teman-temannya.

\section{Implementasi Metode Pembelajaran di Luar Kelas Berbasis Keterampilan Berpikir Kritis}

Proses belajar mengajar adalah faktor penting dalam mendukung keberhasilan guru dalam melaksanakan pembelajaran. Selain itu, kemampuan guru dalam menguasai dan mengimplemantasikan metode pembelajaran 
juga sangat berperan. Dalam memilih metode pembelajaran yang tepat, kadar keaktifan siswa harus selalu menjadi prioritas. Keaktifan siswa harus diusahakan tercipta dan berjalan terus menerus.

Peran guru saat pelaksanaan pembelajaran di luar kelas hanya sebagai fasilitator. Ketika mengajar di dalam kelas, hubungan guru dengan siswa adalah hubungan yang formal, berdasarkan status guru. Namun, saat pembelajaran di luar kelas, guru harus mampu menjadi fasilitator yang hubungannya dengan siswa dalam banyak hal bisa dianggap sama tingkatnya, serta mempunyai hubungan berdasarkan kepercayaan, kehormatan, dan keinginan untuk melayani. Selain itu di dalam kelas, guru mengajar selalu memulai dari pengetahuannya sendiri. Akan tetapi, saat di luar kelas guru yang berfungsi sebagai fasilitator dalam memulai pelajarannya dari pengetahuan siswa.

Pembelajaran tematik adalah pembelajaran yang menggunakan tema dalam mengaitkan beberapa mata pelajaran sehingga dapat memberikan pengalaman bermakna kepada siswa. Untuk meningkatkan keaktifan berpikir siswa dan juga melatih keberaniannya, siswa diajak berdiskusi bagaimana siswa mengungkapkan pendapatnya. Dalam menghadapi masalah-masalah yang terjadi di dalam kelas seperti mengantuk, bosan, gerah, malas, malu berpendapat, dan lain-lain, keterampilan guru dalam memberikan motivasi sangatlah penting dan didukung dengan penggunaan metode pembelajaran yang menyenangkan sehingga membuat siswa tidak merasa jenuh dan membosankan. Maka dari itu, untuk menarik siswa agar aktif maka menggunakan metode pembelajaran di luar kelas yang memanfaatkan sarana dan prasarana yang ada di sekolah SDN Ketabang Surabaya.

Sumber daya untuk mendukung kegiatan pembelajaran, baik guru maupun sarana dan prasarana telah dilakukan. Sekolah juga telah memfasilitasi guru untuk mengembangkan kemampuannya melalui pendidikan dan pelatihan agar memiliki kompetensi dalam mengajar dengan berbagai metode. Salah satu yang digunakan, yaitu metode pembelajaran di luar kelas (outdoor learning).

Implementasi pada setiap keputusan dapat dikatakan berjalan baik. Keputusan telah mengarah kepada tujuan awal metode pembelajaran di luar kelas. Hal tersebut telah disampaikan oleh Ibu Kurida S.Pd., bahwa pembelajaran di luar kelas merupakan usaha untuk menciptakan proses belajar mengajar yang dapat menggali kreativitas dan berpikir kritis siswa.

Konsep pelaksanaan pembelajaran di luar kelas yang telah diterapkan juga memanfaatkan lingkungan untuk menggali daya kreatif dan antusiasme siswa. Berdasarkan hasil observasi siswa memperoleh suasana baru, sehingga siswa lebih gembira dalam proses belajar. Pembelajaran berlangsung dinamis dan tujuan pembelajaran yang diinginkan dapat tercapai.

Perencanaan pembelajaran dilakukan oleh guru kelas dengan menyusun RPP. SDN Ketabang Surabaya melaksanakan Kurikulum 2013 dalam proses pembelajarannya. Hasil penelitian menunjukkan bahwa ketereampilan berpikir kritis di SDN Ketabang Surabaya telah terencana dalam RPP dengan mencantumkan 
kompetensi inti, kompetens dasar, dan indikator kemudian diturunkan dalam langkah-langkah pembelajaran dan ditindaklanjuti dengan penilaian sesuai indikator.

Hasil tersebut sesuai dengan RPP Kurikulum 2013 yang diatur dalam Peraturan Menteri Nomor 22 tahun 2016 tentang Pembelajaran pada Pendidikan Dasar dan Pendidikan Menengah, terdiri dari beberapa komponen yang mencakup (1) identitas sekolah, (2) identitas mata pelajaran atau tema/subtema, (3) kelas/semester, (4) materi pokok, (5) alokasi waktu, (6) tujuan pembelajaran, (6)kompetensi dasar dan indikator pencapaian kompetensi, (7) materi pembelajaran,(8) metode pembelajaran, (9) media pembelajaran, (10) sumber belajar, (11) langkah-langkah pembelajaran, dan (12) penilaian hasil pembelajaran.

RPP disusun mengacu pada silabus yang sudah dibuat dengan memberi tanda pada KD yang memuat materi yang berkaitan dengan karakter kemandirian. Perencanaan penerapan nilai mandir dalam RPP berguna sebagai acuan guru dalam melaksanakan kegiatan pembelajaran. Penulisan Kompetensi Inti, Kompetensi Dasar, dan Indikator di dalam RPP memunculkan kegiatan pembelajaran dan penilaian dari indikator tersebut.

Hasil penelitian tentang keterampilan berpikir kritis berbasis metode pembelajaran di luar kelas di SDN Ketabang Surabaya dalam pelaksanaan pembelajaran yaitu guru mengajak siswa untuk melakukan kegiatan pembukaan dan menjadi pemimpin dalam menyanyikan yel-yel sebelum pembelajaran dimulai. Kedua kegiatan tersebut termuat dalam kegiatan pembuka RPP yang telah dibuat. Pada kegiatan inti pembelajaran, guru memberikan tugas berdiskusi kelompok pada siswa dan kegiatan presentasi di depan kelompok lainnya. Untuk kegiatan akhir pembelajaran, guru menyimpulkan kegiatan pembelajaran yang telah dilakukan pada hari tersebut.

Implementasi metode pembelajaran di luar kelas terhadap keterampilan berpikir kritis siswa di SDN Ketabang Surabaya melalui evaluasi pembelajaran memuat penilaian sikap, pengetahuan dan keterampilan. Contoh penilaian di RPP kelas V tema 4 "Sehat Itu Penting" Subtema 1 "Peredaran Darahku Sehat" pembelajaran 4 pada aspek pengetahuan terdapat pada KD 3.6 Bahasa Indonesia dan penilaian keterampilan pada KD 4.2 PPKn dan pada KD 4.2 IPS.

Hasil tersebut sesuai dengan Permendikbud no 23 Tahun 2016 tentang penilaian hasil belajar siswa pada pendidikan dasar dan pendidikan menengah meliputi aspek sikap, pengetahuan, dan keterampilan. Penilaian aspek sikap (KI 1 dan KI 2) dilakukan melalui observasi atau pengamatan. Penilaian aspek pengetahuan dilakukan melalui tes atau penugasan. Penilaian aspek keterampilan dilakukan melalui praktik, proyek, portofolio.

Penilaian pada RPP digunakan untuk mengukur ketercapaian indikator pada setiap aspek sikap, pengetahuan, dan keterampilan. Implementasi pembentukan nilai kemandirian dalam evaluasi pembelajaran dapat dilaksanakan tidak hanya melalui penilaian sikap, tetapi melalui penilaian pengetahuan dan keterampilan. 


\section{Dampak Dari Implementasi Metode Pembelajara di Luar Kelas Terhadap Keterampilan Berpikir Kritis Siswa Kelas V SDN Ketabang Surabaya}

Implementasi metode ini terhadap keterampila berpikir kritis dapat memberikan dampak poistif. Hal ini disebabkan, selain dapat memberikan pembelajaran yang lebih bermakna, lebih dari itu pembelajaran di luar kelas juga akan membuat pikiran dan semnagat belajar menjadi meningkat, dapat menambah wawasan, bahkan dapat langsung diaplikasikan di lapangan. Dengan belajar di luar kelas yang lebih menyenangkan serta belajar dengan memanfaatkan alam dan lingkungan sekitar sehingga siswa dapat belajar lebih tenang dan bisa berpikir jernih dan dapat menjadikan lebih bervariasi, melihat secara langsung hal-hal secara nyata.

Terlihat dari ekspresi muka siswa sangat gembira dan antusias melakukan pembelajaran di luar kelas dan peneliti membuktikan dengan wawancara dari beberapa siswa kelas V A yang sedang melakukan pembelajaran di luar kelas:

"Iya Bu Sabrina, saya senang belajar di luar kelas sambil bermain serta langsung melihat interaksi yang ada di sekolah. Jadi saya langsung mengamati dan bisa mempraktikkan secara langsung".

Di dalam pembelajaran kelas V A, ternyata terdapat dampak negatif juga, antara lain: 1) menyita banyak waktu; 2) membutuhkan tenaga yang ekstra. Artinya, guru harus mampu mengelola waktu dengan baik, sehingga materi yang diajarkan dapat tersampaikan, serta pembelajaran tidak terkesan hanya bermain. Tujuannya, agar siswa mampu memahami materi apa saja yang telah diajarkan. Selain itu, dalam proses pembelajaran diharapkan dapat meningkatkan kerja sama yang baik antara guru dan siswa untuk memperbaiki segala sistem yang digunaka dalam melaksanakan kegiatan pembelajaran di SDN Ketabang Surabaya.

Harapan dari kegiatan pembelajaran yang menggunakan metode pembelajaran di luar kelas ini adalah agar siswa dapat berpikir kritis dan mampu memiliki semangat yang tinggi untuk belajar, tidak merasa bosan saat pembelajaran hanya di dalam kelas, dan melatih konsentrasi siswa saat pembelajaran berlangsung.

\section{Pembahasan}

Pembelajaran Tematik merupakan pembelajaran yang sudah diterapkan oleh SDN Ketabang Surabaya sejak dilaksanakannya kurikulum 2013. Semua pembelajaran harus mempunyai perencanaan yang matang begitu pula dengan pelajaran Tematik. Untuk itu guru dituntut untuk menyajikan dan menyampaikan materi dengan tepat. Guru diharapkan untuk mempersiapkan sebelumnya materi yang akan diajarkan agar dapat melaksanakan dan menilai hasil-hasil siswa dengan baik, dapat memilih strategi dan metode belajar mengajar dengan tepat, mengelola kelas, dan membimbing perkembangan siswa dengan tepat.

Langkah-langkah pembelajaran di luar kelas sesuai dengan Rencana Pelaksanaan Pembelajaran (RPP) oleh guru kelas V A SDN Ketabang Surabaya. Perencanaan ini diawali dengan tema yang disesuaikan dengan kurikulum 2013. Guru terlebih dahulu melihat tema mana yang bisa diterapkan metode pembelajaran di luar kelas dan tentu saja tempatnya di sekeliling halaman sekolah. 
Metode pembelajaran di luar kelas menggunakan setting alam terbuka sebagai sarana. Proses pembelajaran menggunakan alam dan lingkungan sebagai media dipandang sangat efektif dalam melaksanakan pembelajaran di luar kelas. Dimana setiap siswa dapat merasakan, melihat langsung bahkan dapat melakukan sendiri, sehingga dapat mentransfer pengetahuan berdasarkan pengalaman di alam dan lingkungan terbuka. Seperti pada tema "Sehat Itu Penting" yang membahas tentang interaksi lingkungan dan kewajiban yang dilakukan oleh manusia terhadap lingkungan sekolah, lingkungan rumah, dan lingkungan alam.

Berdasarkan pembahasan tersebut, terdapat kesesuaian antara temuan dan teori yang digunakan. Untuk itu, peneliti memberi pernyataan bahwa dalam proses pembelajaran di luar kelas mencakup tujuan perencanaan, sumber daya, pengaplikasian setiap keputusan yang ada. Artinya, penetapan tujuan, perencanaan setiap kegiatan serta penyusunan silabus dan Rencana Pelaksanaan Pembelajaran yang sesuai dengan konteks tema dan pembelajaran dapat dibuktikan.

Peneliti dapat menyimpulkan bahwa langkah-langkah perencanaan metode pembelajaran di luar kelas pada pembelajaran Tematik di SDN Ketabang Surabaya meliputi: a) melihat materi dalam materi yang ada di tema, b) untuk tempat memanfaatkan lingkungan dan halaman sekolah, c) menentukan aspek-aspek atau permasalahan yang akan diselidiki, d) menyusun Rencana Pelaksanaan Pembelajaran.

Dalam implementasi pembelajaran di luar kelas yang ditujukan untuk mengukur keterampilan berpikir kritis siswa, guru mampu melaksanakan pembelajaran dengan baik dan sesuai harapan. Implementasi metode pembelajaran di luar kelas melalui kegiatan pembelajaran tidak terlepas pula dari suatu kendala. Kendala bisa saja terjadi karena beberapa faktor. Kendala tersebut tentu bukanlah suatu hal yang diinginkan oleh setiap orang. Namun, tak bisa dipungkiri bahwa setiap kegiatan dalam pelaksanaannya tentu sedikit atau banyak akan menemukan suatu kendala.

Dalam implementasi metode pembelajaran di luar kelas melalui kegiatan pembelajaran di SDN Ketabang Surabaya terdapat beberapa kendala. Yang pertama kendala tersebut berasal dari siswa. Tidak semua siswa mampu konsentrasi saat guru memberikan materi, tidak semua siswa mampu berperan aktif dalam diskusi kelompok dan tida semua siswa mampu berpikir kritis saat pembelajaran berlangsung. Tentu ada satu atau dua siswa yang kurang mendukung dan menghambat jalannya kegiatan pembelajaran. Misalnya, siswa yang tidak serius dan melihat pekerjaan kelompok sebelahnya saat mengerjakan tugas, kemudian terdapat anggota kelompok yang tidak mau membantu dalam mengerjakan tugas saat berdiskusi kelompok, kemudian saat presentasi di depan kelompok lainnya bersama anggota kelompok masih ada beberapa anggota kelompok yang terlihat tidak siap dan kurangnya kekompakan, dan masih banyak siswa yang kurang mampu dalam menyimpulkan kegiatan pembelajaran yang telah dilakukan pada hari itu.

Menurut Ibu Kurida S.Pd. selaku guru kelas V A bahwa siswa kelas V A sangatlah senang dan semangat apabila pembelajaran dilaksanakan di luar kelas. Mereka lebih aktif dan antusias untuk mengikuti pembelajaran 
tersebut. Selain itu, mereka juga bisa berinteraksi langsung dengan alam atau lingkungan sekitar. Sehingga $\mathrm{Bu}$ Kurida terlebih dahulu menyesuaikan materi yang akan diajarkan dengan metode yang belaiu pakai.

Inilah yang menentukan keberhasilan kegiatan belajar di luar kelas dan mampu mendorong para siswa memahami materi yang diajarkan bahkan lebih memahami daripada belajar di dalam kelas. Oleh karena itu seorang guru yang melaksanakan metode ini harus memahami peran seorang guru sebagai fasilitator. Pelaksanaan pembelajaran di luar kelas membuat siswa kelas V A lebih aktif dan menumbuhkan keberanian. Siswa mampu menggali sendiri pengentahuannya dengan cara mengamati dan wawancara kepada narasumber.

Implementasi metode pembelajaran di luar kelas terhadap keterampilan berpikir kritis siswa di SDN Ketabang Surabaya melalui evaluasi pembelajaran memuat penilaian sikap, pengetahuan dan keterampilan. Contoh penilaian di RPP kela V tema 4 "Sehat Itu Penting" Subtema 1 "Peredaran Darahku Sehat" pembelajara 4 pada aspek pengetahuan terdapat pada KD 3.6 Bahasa Indonesia dan penilaian keterampilan pada KD 4.2 PPKn dan pada KD 4.2 IPS.

Kelamahan metode ini meliputi: (a) siswa akan kurang kosentrasi (b) pengelolaan siswa akan lebih sulit terkondisi (c) penguatan konsep kadang terkontaminasi oleh siswa lain atau kelompok lain.

Tahap penyelesaian atau tindak lanjut dari pelaksanaan pembelajaran di luar kelas adalah berupa evaluasi dan pemahaman dalam objek yang mereka kunjungi. Tindak lanjut dalam pelaksanaan pembelajaran di luar kelas mereka melakukan diskusi dengan kelompok dan dipresentasikan. Dengan begitu mereka paham tentang materi "Sehat Itu Penting" Subtema 1 Pembelajaran 4.

\section{KESIMPULAN}

Berdasarkan hasil penelitian, dapat ditarik kesimpulan terkait implementasi metode pembelajaran di luar kelas berbasis keterampilan berpikir kritis pada Kelas V Tema 4 Sehat Itu Penting Subtema 1 Peredaran Darahku Sehat Pembelajaran 4 SDN Ketabang Surabaya sesuai dengan rumusan masalah yang diangkat. Metode pembelajaran di luar kelas adalah serangkaian kegiatan belajar mengajar yang dilaksanakan di luar kelas atau alam terbuka, sebagai kegiatan pembelajaran siswa. Dengan kegiatan pembelajaran di luar kelas, siswa dapat mengenal dan berinteraksi dengan alam secara dekat. Jadi, bagi siswa bukan hanya kegiatan hiburan untuk bersenang-senang saja, tetapi mengandung nilai edukatif yang sangat tinggi.

Adapun implementasi metode pembelajaran di luar kelas pada tem "Sehat Itu Penting" Subtema 1 Pembelajaran 4 siswa kelas V A SDN Ketabang Surabaya meliputi: (a) Observasi atau mengamati objek yang mereka temui di alam atau lingkungan sekitar; (b) Diskusi dengan kelompok untuk mengumpulkan informasi dari tahap pembukan sampai penutup pembelajaran; (c) Evaluasi untuk mengetahui seberapa jauh siswa memahami materi yang telah disampaikan oleh guru. Dampak implementasi pembelajaran metode di luar kelas pada tema "Sehat Itu Penting" Subtema 1 Pembelajaran ke 4 siswa kelas V A SDN Ketabang Surabaya meliputi: (a) Dampak positif siswa akan lebih senang dan semangat belajar di luar kelas karena langsung 
berhubungan dengan alam terbuka dan lingkungan sekitar sehingga siswa akan lebih santai dan berpikir kritis. Mengamati interaksi dan kewajiban apa saja yang ada di lingkungan sekolah. (b) Dampak negatif dari pembelajaran di luar kelas ini menyita banyak waktu dalam satu kelas dibagi menjadi 9 kelompok dan masingmasing kelompok harus mengamati interaksi yang ada di lingkungan sekolah. Selain menyita banyak waktu juga membutuhkan tenaga yang lebih karena aktivitas siswa lebih aktif daripada di dalam kelas.

\section{DAFTAR PUSTAKA}

Abdurrahman. 1995. Metode Penelitian Komunikasi. Bandung: PT Remaja Rosdakarya.

Arikunto, Suharsimi. 2010. Prosedur Penelitian Suatu Pendekatan Praktik. Jakarta: Rineka Cipta.

Dewi, Erni Ratna. 2018. "Metode Pembelajaran Modern dan Konvensional pada Sekolah Menengah Atas". Dalam Jurnal Pembelajar: Jurnal Ilmu Pendidikan, Keguruan, dan Pembelajaran, Vol. 2(1): 44-52

Dimyati dan Mudjiono. 2002. Belajar dan Pembelajaran Cetakan Kedua. Jakarta: PT Rineka Cipta

Djamarah, Syaiful Bahri dan Zain, Aswan. 2010. Strategi Belajar Mengajar. Jakarta: Rineka Cipta

Eggen, Paul dan Kauchak, Don. 2012. Strategi dan Model Pembelajaran. Jakarta: PT. Indeks

Hanik, Nur Rokhimah dkk. 2018. "Penerapan Pendekatan Contextual Teaching and Learning dengan Metode Observasi untuk Meningkatkan Hasil Belajar pada Matakuliah Ekologi Dasar." Dalam Jurnal Pendidikan Matematika dan IPA, Vol. 9(2): 127-138.

Harsanto, Radno. 2005. Melatih Anak Berpikir Analitis Kritis dan Kreatif. Jakarta: PT Gramedia Widiasarana Indonesia

Hassoubah, Zaleha Izhab. 2004. Cara Berpikir Kreatif dan Kritis. Bandung: Nuansa

Husamah. 2013. Pembelajaran di Luar Kelas (Outdoor Learning). Jakarta: Prestasi Pustaka Raya Publisher

Iskandar. 2009. Metodologi Penelitian Kualitatif. Jakarta: Gaung Persada Press.

Moeslichatoen, R. 2004. Metode Pengajaran di Taman Kanak-Kanak. Jakarta: Rineka Cipta.

Musfiqon, HM. 2012. Metodelogi Penelitian Pendidikan. Jakarta: Prestasi Pustakaraya.

Rachmadtullah, Reza, Via Yustitia, Bramianto Setiawan, Arif Mahya Fanny, Pana Pramulia, Wahyu Susiloningsih, Cholifah Tur Rosidah, Danang Prastyo, and Trio Ardhian. 2020. "The Challenge Of Elementary School Teachers To Encounter Superior Generation In The 4.0 Industrial Revolution: Study Literature." International Journal of Scientific \& Technology Research 9(4):1879-82.

Rosyid, Mohammad Zaiful dkk. 2019. Outdoor Learning Belajar di Luar Kelas. Malang: CV. Literasi Nusantara Abadi.

Sanjaya, Wina. 2007. Strategi Pembelajaran Berorientasi Standar Proses Pendidikan. Jakarta: Kencana Prenada Media Group

Sugiyono. 2014. Metode Penelitian Kuantitatif, Kualitatif dan R\&D. Bandung: PT Alfabeta.

Sugiyono. 2016. Metode Penelitian Kuantitatif, Kualitatif dan R\&D. Bandung: PT Alfabeta.

Suryosubroto, B. 2010. Manajemen Pendidikan di Sekolah. Jakarta: Rineka Cipta. 